\title{
Sosialisasi Literasi Positif Melalui Media Sosial "Steemit" pada Santri Dayah Darul Muta'llimin Aceh Barat
}

\author{
Putri Maulina \\ Jurusan Ilmu Komunikasi, Universitas Teuku Umar \\ Email: putrimaulina@utu.ac.id
}

Submitted: 18 November 2019 Revised: 26 November 2019 Accepted: 09 Desember 2019

\begin{abstract}
Positive literacy is the ability of individuals in languages such as writing, reading, or speaking well that has a positive impact. In the era of development of communication and information technology, one of the media that can increase the ability to titrate is social media. Steemit is a weblog type social media that has been popular since 2017. The aim of this service is to be able to socialize the concept of positive literacy by using the new Steemit social media on Santri Dayah Darul Muta'allimin, West Aceh. Service methods used are lectures and training. The results obtained in this service are strengthening of students with an emphasis on understanding the concept of positive literacy, techniques for registering and using social media Steemit, as well as understanding about building networks and getting rewarded through literacy on Steemit social media.
\end{abstract}

Keyword: Literacy, Social Media, Steemit

\begin{abstract}
Abstrak
Literasi positif merupakan kemampuan individu dalam berbahasa seperti menulis, membaca, atau berbicara secara baik yang memberikan dampak secara positif. Di era perkembangan teknologi komunikasi dan informasi, salah satu media yang dapat meningkatkan kemampuan berliterasi adalah media sosial. Steemit merupakan media sosial berjenis weblog yang populer sejak tahun 2017. Tujuan dari pengabdian ini adalah untuk dapat mensosialisasikan konsep literasi postif dengan menggunakan media sosial baru Steemit pada Santri Dayah Darul Muta'allimin, Aceh Barat. Metode pengabdian yang digunakan adalah ceramah dan pelatihan. Adapun hasil yang didapatkan pada pengabdian ini adalah penguatan pada santri dengan penekanan pada pemahaman tentang konsep literasi positif, teknik mendaftar dan menggunakan media sosial Steemit, serta pemahaman tentang membangun jaringan dan memperoleh reward melalui literasi di media sosial Steemit.
\end{abstract}

Kata Kunci: Literasi, Media Sosial, Steemit

\section{PENDAHULUAN}

Setelah infrastruktur dari media internet mengalami pengembangan, beberapa di antaranya melalui pengembangan infrastuktur berbentuk akses wifi, jaringan fiber dan lain sebagainya Indonesia menjadi salah satu negara yang memiliki jumlah pengguna media sosial terbesar di dunia. Pengguna
Facebook, Twitter, Instagram dan lainlain dari Indonesia menempati porsi yang cukup besar dari keseluruhan pengguna media sosial tersebut. Meningkatnya penggunaan media sosial di kalangan masyarakat Indonesia ini sejalan dengan berkembangnya era media baru yaitu internet. Sejalan dengan hal itu, saat ini media konvensional 
mulai tergantikan dengan hadirnya media sosial karena kemudahannya menjangkau berbagai orang di belahan dunia dengan cepat dan tanpa batas.

Data dari beberapa lembaga survey menguatkan wacana peningkatan pengguna sosial media di Indonesia dalam beberapa tahun ini. Salah satunya adalah Asosiasi Penyelenggara Jasa Internet Indonesia (APJII), yang memaparkan bahwa pada tahun 2012, kurang lebih 63 juta masyarakat Indonesia terhubung dengan internet dan sebanyak 95 persen aktivitas yang mereka lakukan adalah adalah membuka media sosial.

Karena peningkatan ini, Indonesia diprediksi akan menjadi negara dengan pengguna sosial media paling aktif dan paling banyak. Faktor yang memungkinkan hal ini dapat terjadi adalah kemudahan mendapatkan perangkat teknologi komunikasi atau gawai yang memungkinkan akses internet melalui sistem mobile, sehingga pengguna lebih punya kesempatan untuk mengakses jaringan secara lebih leluasa. Tetra Pak Index mencatat bahwa ada lebih dari 106 juta orang Indonesia menggunakan media sosial tiap bulannya. Di mana $85 \%$ diantaranya mengakses sosial media melalui perangkat seluler. (detiknews.com, edisi 27 September 2017

Berdasarkan data tersebut, dapat tergambarkan secara jelas bahwasanya masyarakat Indonesia semakin hari semakin aktif dalam bermedia sosial, dengan tingkat penetrasi yang mencapai puluhan juta orang. Semakin tingginya peningkatan penggunaan media sosial dapat meungkinkan penyebaran konten ataupun informasi secara lebih mudah. Bahkan sampai informasi terkecil pun dapat menjadi perbincangan secara cepat oleh masyarakat di dunia media sosial.

Oleh karena itu, dampak dari menjamurnya media sosial sebagai bagian dari media baru adalah kemudahan untuk mengakses informasi dan kemudahan untuk memberikan pengaruh negatif bagi penggunanya. Dennis Mcquail, menjelaskan bahwa ciri-ciri media baru adalah 1.) interkonektivitas, yaitu adanya akses terhadap khalayak individu, dan 2.) interaktivitas, yaitu kegunaan beragam untuk berbagai macam jenis manusia. Interkonektivitas berarti adanya hubungan antara satu perangkat dengan perangkat yang lain, sementara interaktivitas berarti di dalam media baru memiliki peluang untuk melakukan interaksi antara pengguna dengan pengguna yang lain. Ciri-ciri ini kemudian juga memungkinkan 
untuk memperluas peluang penyebaran informasi bohong atau hoax di tengah-tengah para pengguna media sosial di Indonesia, memperkuat kasus bullying, cybercrime, atau penistaan bernuansa SARA.

Disisi lain, kasus-kasus penyalahgunaan media internet oleh masyarakat Indonesia telah dibatasi di dalam Undang-Undang Nomor 11 Tahun 2008 Tentang Informasi dan Transaksi Elektronik (UU ITE). Yang mana undang-undang tersebut mendorong masyarakat Indonesia untuk terhindar dari penyalahgunaan internet, yang berimplikasi pada keberlangsungan berbangsa dan bernegara.

Untuk itu, sangat penting adanya suatu pemanfaatan media sosial positif yang dapat mengawasi secara ketat para penggunanya. Tahun 2016, muncul lah suatu platform media sosial yang berbeda di tengah-tengah masyarakat Indonesia. Media sosial ini dikenal dengan nama Steemit, sebuah platform media sosial positif yang di dalamnya memberikan penghargaan kepada pengguna, baik untuk postingan tulisantulisannya, maupun untuk memberikan voting pada postingan orang lain yang dianggap menarik.

Steemit ini dianggap sebagai media sosial yang berbeda, karena mampu mengawasi penggunanya untuk tidak sewenang-wenang atau berlebihan dalam bermedia sosial. Di dalam media jenis ini, penggunanya diberikan aturanaturan atau batasan untuk tidak saling mencaci-maki, menyinggung hal yang berkaitan dengan SARA, melakukan plagiasi, atau menebarkan informasi hoax.

Oleh karena itu, dalam dua tahun pertamanya media sosial ini berhasil minat banyak pengguna. Indonesia bahkan menduduki peringkat ke 15 pengguna Steemit terbanyak, dan Aceh menduduki peringkat pertama sebagai pengguna Steemit terbanyak di kalangan pengguna media sosial di Indonesia.

Keberadaan media sosial positif ini diperlukan untuk mendukung tumbuh kembangnya literasi di tengah-tengah masyarakat Indonesia, khususnya di Aceh. Steemit ini diharapkan mampu memberikan motivasi bagi para penggunanya untuk lebih berhatihati dalam menulis dan meningkatkan kualitas penulisannya agar dapat menjangkau reward yang tinggi.

Peningkatan literasi di tengahtengah masyarakat itu sangatlah penting, salah satunya adalah dengan membangun kesadaran budaya membaca dan menulis yang baik. Menumbuhkembangkan budaya berliterasi yang positif bagi 
kalangan masyarakat akan mendorong terhindarnya penyalahgunaan media-media sosial.

Salah satu pihak yang juga perlu diberikan dorongan untuk berliterasi melalui platform media sosial positif jenis Steemit ini adalah kalangan santri. Adapun santri merupakan kalangan yang diharapkan mampu menjadi pioner dakwah bagi masyarakat, dan untuk menyebarluaskan dakwah salah satunya adalah dengan turut serta mengikuti perkembangan teknologi informasi. Santri harus mampu memanfaatkan platform media sosial untuk sarana dakwah modern, dan salah satu yang bisa digunakan adalah media sosial positif Steemit ini.

Oleh karena itu, untuk mengatasi permasalahan penyalahgunaan media sosial dan peningkatan literasi bagi kalangan santri sebagai pioner dakwah modern, maka pihak pengelola Dayah Darul Muta'allimin mengadakan program kegiatan pengenalan media sosial positif bagi kalangan santri dengan tema "Steemit Goes to Dayah" dan tajuk "Pentingnya Steemit untuk Meningkatkan Literasi dan Benefit di Dayah Darul Muta'allimin Meulaboh, Aceh Barat". Pengenalan media sosial positif ini dianggap penting untuk menumbuhkembangkan potensi berliterasi santri, untuk dapat diarahkan secara tepat dan bermanfaat.

\section{METODE PELAKSANAAN}

Materi yang diberikan dalam kegiatan sosialisasi ini adalah pemberian pemahaman mengenai pentingnya literasi dengan memanfaatkan sosial media yang positif bernama Steemit. Adapun tujuan dilakukan sosialisasi pengenalan media Steemit ini adalah guna mendukung peningkatan literasi melalui trend media sosial baru yang sedang berkembang di Aceh.

Kegiatan dilakukan dengan melihat pada permasalahan bahwa masih minimnya pemahaman santri terhadap pentingnya literasi positif dengan memanfaatkan media sosial baru. Oleh karena itu, diadakan suatu pelaksanaan pengabdian masyarakat pada tahun 2018 untuk memperkenalkan jenis media sosial baru bernama Steemit sebagai salah satu platform media sosial yang menjamin tumbuh kembangnya literasi penggunanya agar dapat bermedia sosial secara positif.

Yang menjadi sasaran dari kegiatan ini adalah kalangan Mahasantri Dayah Darul Muta'allimin, Aceh Barat. Mahasantri adalah santri yang berada di tingkatan mahasiswa, dan dianggap telah punya wawasan 
dasar tentang pemberdayaan teknologi informasi seperti media jejaring sosial. Mahasantri juga merupakan pihak yang dapat lebih mudah didorong dan diberikan pemahaman mengenai pentingnya berliterasi dengan menggunakan platform media modern seperti Steemit. Selain itu, mahasantri juga dianggap layak untuk diperkenalkan jenis media yang mampu memberikan alternatif benefit atau penghasilan sebagai penunjang kebutuhan sehari-hari mereka.

Platform media sosial Steemit ini bertujuan untuk mewadahi penggunanya agar dapat memposting konten-konten berkualitas, baik berupa tulisan, foto, video, atau desain grafis. Sehingga melalui Steemit, para penggunanya dapat termotivasi untuk menulis secara lebih baik. Manfaat dari kegiatan sosialisasi ini adalah dapat mendorong motivasi dan wawasan mahasantri untuk dapat berliterasi dengan Steemit sehingga mampu menjadi pioner dakwah modern di bumi Teuku Umar ini.

Proses pelaksanaan sosialisasi ini dilakukan dengan dua metode: 1 ) Ceramah atau diskusi materi; 2) dan pelatihan, yaitu dengan pembentukan kelompok-kelompok kecil di akhir sesi materi. Ceramah dilakukan untuk memaparkan konsep-konsep mengenai literasi, pentingnya menulis, alasan menulis, media-media untuk menulis, apa itu Steemit, dan proses registrasi akun Steemit. Metode ceramah dikombinasikan dengan memanfaatkan media laptop dan LCD untuk menampilkan power point materi mnegnai literasi dan media sosial baru Steemit serta contoh gambar-gambar proses pendaftaran akun media sosial Steemit.

Sedangkan metode pelatihan melalui pembentukan kelompokkelompok kecil diakhir sesi dilakukan agar peserta dapat mempraktikkan secara langsung proses registrasi akun Steemit. Peserta sosialisasi diberikan arahan untuk membuat akun Steemit secara langsung melalui gawai pribadinya. Bagi yang belum mempunyai email, maka peserta dituntun untuk membuat sebuah email yang digunakan untuk proses pendaftaran akun Steemit.

\section{HASIL DAN PEMBAHASAN}

Pelaksanaan sosialisasi diadakan sebanyak dua sesi, yaitu sesi materi untuk membahas beberapa hal, yaitu: Untuk apa menulis? Alasan menulis? Di mana menulis? Apa itu Steemit? Mengapa harus Steemit? Bagaimana Menggunakan Steemit?. 
Materi dapat disampaikan dengan baik dan lancar, dan peserta juga merespons secara antusias dan bersemangat. Meskipun tidak dapat disampaikan secara detail mengenai konsep-konsep asing di dalam pengaturan Steemit, karena mempertimbangkan keterbatasan waktu.

Kemampuan peserta dalam memahami materi cukup baik. Hal ini diukur dari antusiasme peserta pada sesi tanya jawab. Beberapa pertanyaan yang diajukan oleh peserta adalah (2) Bagaimana cara mengklaim reward di Steemit, (2) Hal-hal apa saja yang perlu diperhatikan seorang penulis agar tidak mendapatkan sanksi di Steemit, dan (3) Cara mengatur waktu agar dapat konsisten menulis di Steemit.

Adapun pada sesi praktik, sedikit terkendala di permasalahan jaringan untuk terkoneksi dengan jaringan internet. Sehingga butuh waktu untuk dapat mendaftarkan peserta ke laman Steemit, dan hanya sebagian peserta saja yang berhasil didaftarkan akunnya. Kendala juga terletak pada tidak tersedianya jaringan Wifi di area sosialisasi dan dengan hanya mengandalkan gawai dari masing-masing peserta.

Untuk itu, pemateri mengarahkan beberapa peserta yang berhasil didaftarkan ke akun Steemit untuk diberikan pemahaman secara lebih intensif sehingga dapat membantu rekan-rekannya yang lain nanti.

Adapun hasil pelaksanaan pengabdian masyarakat secara insidental ini secara garis besar dapat dipaparkan sebagai berikut:

\section{Pentingnya Literasi Positif}

Literasi secara luas dapat diartikan sebagai bentuk kemampuan berbahasa yang meliputi kemampuan menyimak, berbicara, membaca, dan menulis, serta kemampuan berpikir yang menjadi elemen di dalamnya (Padmadewi dan Artini, 2018: 1-2).

Sedangkan budaya literasi positif merupakan suatu upaya melakukan kebiasaan berfikir yang diikuti dengan sebuah proses membaca dan menulis yang pada akhirnya kegiatan tersebut dapat melahirkan suatu karya positif yang dapat memberikan manfaat pada diri sendiri dan orang lain.

Metode yang digunakan agar dapat menyalurkan materi kepada peserta sosialisasi adalah metode ceramah. Dengan memperkenalkan konsep literasi positif melalui metode ceramah, mahasantri Dayah Darul Muta'allimin menjadi paham bahwa menulis merupakan salah satu bagian yang perlu dilakukan, terutama bagi kalangan muda untuk dapat menyalurkan ide dan gagasan secara kreatif. Adapun pelaksanaan 
pengabdian yang dilakukan dapat

dilihat pada gambar 1 berikut:

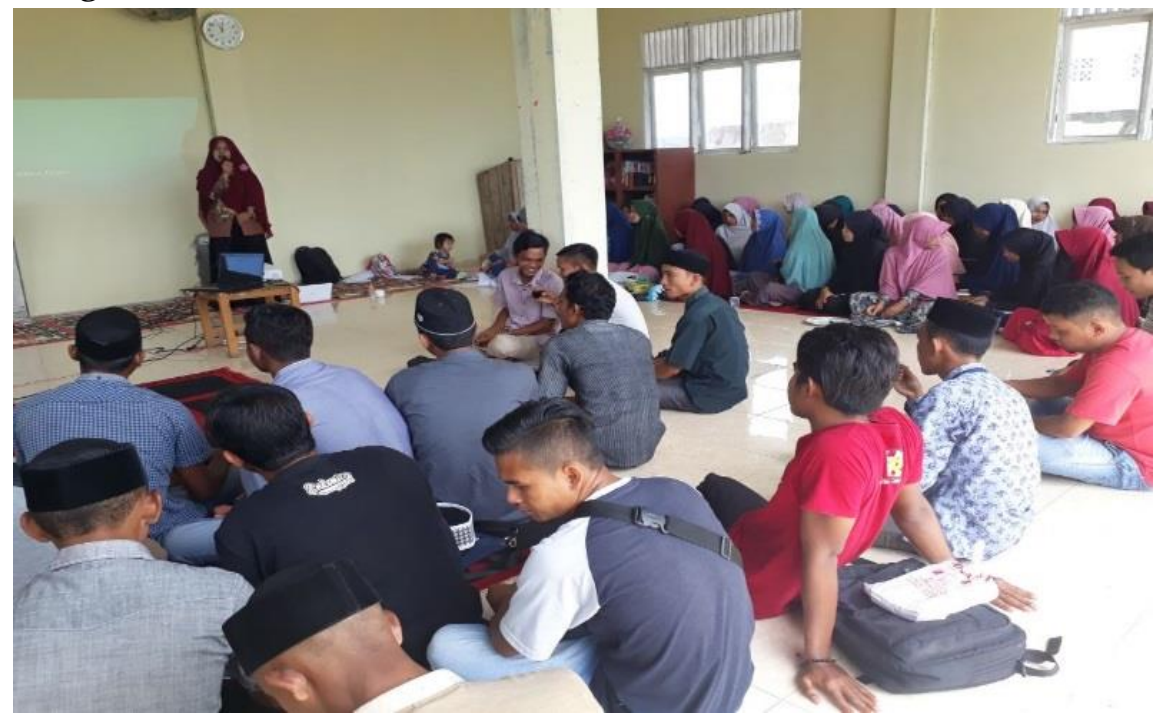

Gambar 1: Peserta Diberikan Materi Tentang Literasi dan Sosial Media Positif

Ceramah dilakukan dengan cara memberikan materi-materi yang berkaitan dengan hal-hal dasar tentang konsep literasi. Ada beberapa poin penting yang dijelaskan kepada mahasantri tentang literasi positif:

Pertama, literasi merupakan bagian yang harus dimiliki generasi muda, khususnya santri.

Kedua, literasi adalah kemampuan sehingga perlu ditingkatkan. Peningkatan literasi dapat dilakukan dengan lebih banyak berlatih memperbaiki kemampuan berbahasa, melalui membaca, menulis, atau berbicara.

Ketiga, literasi butuh tempat untuk disalurkan. Media massa merupakan salah satu wadah yang dapat dijadikan sebagai sarana pengembangan literasi. Untuk meningkatkan literasi positif, maka santri harus mampu menggunakan media yang positif.

\section{Literasi Positif Dengan Media Sosial Steemit}

Steemit merupakan salah satu media sosial berbentuk weblog yang fungsinya untuk menjadi wadah penguatan literasi penggunanya. Melalui media sosial ini, penggunanya dapat mengunggah konten-konten kreatif dalam bentuk tulisan, foto, video, atau desain grafis.

Berbeda dengan media sosial lainnya, Steemit dapat mengontrol penggunanya untuk membagikan konten-konten positif yang dikendalikan dengan kebijakankebijakan untuk tidak menggunggah sesuatu yang mengarah pada bentuk 
plagiarisme. Plagiarisme pada dasarnya adalah upaya untuk menggunakan hasil karya orang lain, seakan-akan merupakan hasil karyanya sendiri (Indriati, 2015: 2).

Media sosial ini juga memungkinkan penggunakan untuk mendapatkan penghargaan terhadap apa yang diunggahnya berupa Steem Power dan Steem Dollar yang kemudian dapat dipertukarkan dalam bentuk koin digital, atau dikenal dengan bitcoin.

Pada sesi pelatihan, setiap mahasantri diarahkan untuk membuat akun Steemit untuk menjadi wadah penyaluran literasi positif. Pelatihan merupakan salah satu metode penting dalam pengabdian untuk dapat

mengenalkan secara langsung tentang teknik-teknik dasar menggunakan sosial media Steemit tersebut, sehingga dapat diketahui secara tuntas apa yang menjadi kendala dan peluang yang terjadi ketika berada di lapangan.

Praktik langsung untuk dapat mengkomunikasi secara efektif bagaimana bentuk media sosial Steemit dapat dilakukan dengan cara membuat kelompok-kelompok kecil. Pada sesi praktik tersebut, peserta diarahkan untuk dapat membuat akun dengan masingmasing dengan menggunakan laptop atau smartphone yang dimilikinya, seperti yang terlihat pada gambar 2 berikut:

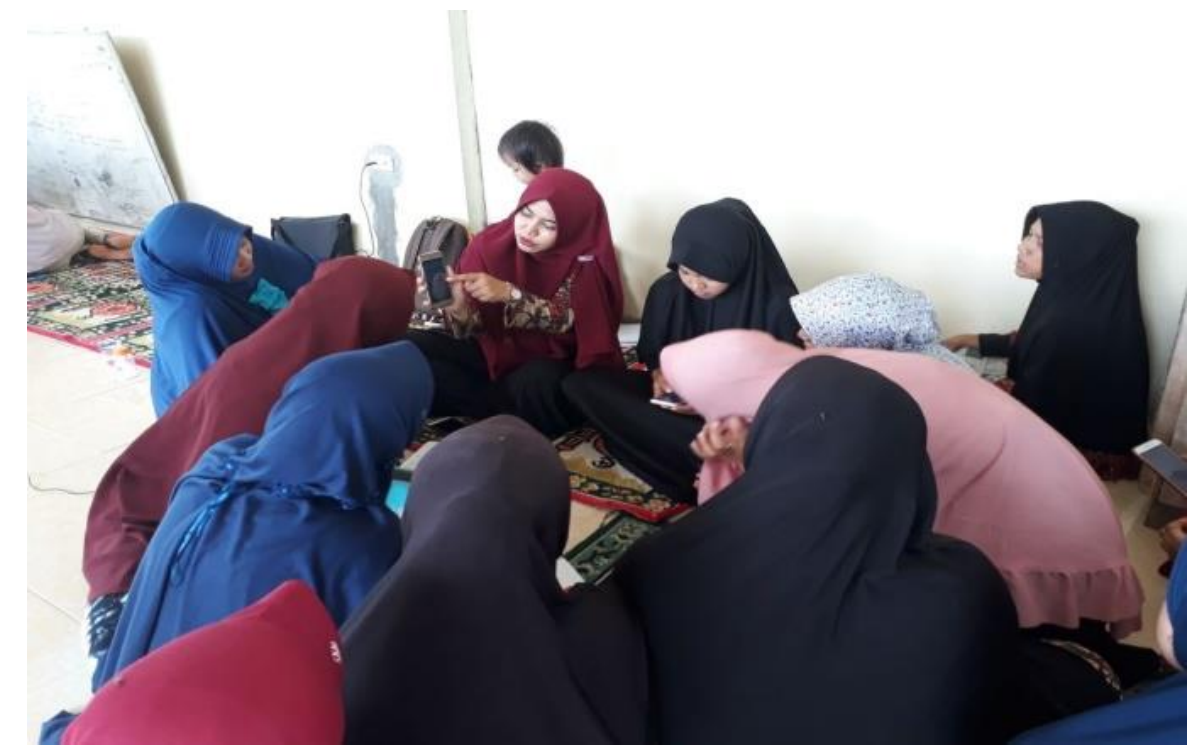

Gambar 2. Peserta Diarahkan untuk Membuat Akun Steemit

Ada beberapa hal yang diajarkan pada sesi pelatihan tersebut: pertama, teknik membuat email yang akan digunakan sebagai akun login ke media sosial Steemit; kedua, teknik registrasi ke akun Steemit; ketiga, 
membedah fitur-fitur penting yang ada pada Steemit dan teknik menggunakan fitur-fitur tersebut; keempat, cara mengembangkan pertemanan dan jaringan; kelima, cara mengklaim reward yang diperoleh dari hasil publikasi konten yang telah dilakukan; dan keenam kebijakan-kebijakan yang harus dipatuhi dan dilakukan penggunanya ketika menggunakan Steemit.

Adapun pembahasan hasil dari kegiatan pelaksanaan pengabdian masyarakat ini dapat digambarkan secara garis besar sebagai berikut:

Keberhasilan Target Peserta Sosialisasi, target peserta kegiatan sosialisasi Steemit ini dinilai cukup baik, dengan melihat kehadiran peserta di atas 30 orang. Jumlah ini menunjukkan bahwa hampir keseluruhan Mahasantri Dayah Darul Muta'allimin ikut serta dalam kegiatan sosialisasi ini.

Ketercapaian Tujuan Sosialisasi, terbatasnya waktu dan fasilitas teknologi Wifi atau internet menyebabkan sedikit hambatan dalam proses sosialisasi. Materi tidak dapat disampaikan secara sangat mendetail, terutama mengenai penjelasan istilah-istilah asing dalam media Steemit. Sehingga materi hanya disampaikan secara garis besar saja mengenai dasar dari pentingnya literasi dan memanfaatkan media postif Steemit.

Berdasarkan hasil survey sederhana dengan menggunakan kuisioner dan menghitung nilai ratarata (mean) dari total peserta yang hadir sebanyak 30 peserta, maka untuk indikator antusiasme secara keseluruhan menggambarkan yang disampaikan dapat diterima secara baik oleh peserta sosialisasi. Hal ini juga ditunjukkan dengan adanya antusiame peserta dalam sesi tanyajawab dan keterlibatan mereka dalam praktik langsung pendaftaran Steemit. Sehingga ketercapaian tujuan dari sosialisasi dapat dinilai baik $(>80 \%)$, dengan adanya peningkatan kesadaran peserta untuk lebih berpartisipasi pada pemanfaatan media sosial positif demi meningkatkan literasi santri.

Target Penyampaian Materi, materi dapat disampaikan dengan baik melalui pemanfaatan LCD dan praktik langsung kepada peserta. Adapun materi yang disampaikan adalah: (a) Dasar-dasar literasi, (b) Mengapa perlu menulis, (c) Media tempat menulis, (d) Apa itu Steemit, (e) Bagaimana cara mendaftar Steemit, dan (f) Apa-apa saja yang harus diperhatikan ketika menulis di Steemit.

Kemampuan Peserta Memahami materi yang Disampaikan. Survey sederhana yang dilakukan kepada peserta setelah sosialisasi terhadap indikator pemahaman materi, maka nilai rata-rata (mean) menunjukkan hasil bahwa peserta dapat memahami materi dengan cukup baik (>70\%). Peserta tidak mampu memahami sepenuhnya materi 
karena keterbatasan waktu dan fasilitas untuk praktik secara memadai. Juga didukung dengan latar belakang kemampuan peserta yang berbeda-beda dalam memahami dasar-dasar dari teknologi informasi.

Pelaksanaan

pengabdian

masyarakat tentang sosialisasi media sosial Steemit ini menggambarkan bahwa proses berliterasi melalui penggunaan media baru adalah hal yang penting. Literasi di media sosial Steemit memungkinkan Mahasantri Dayah Darul Muta'allimin untuk melakukan interkonektivitas dan interaktivitas antar sesama penggunanya di berbagai daerah, sehingga proses dakwah dapat dilaksanakan secara lebih efektif. Sebagai bentuk evaluasi, mahasantri yang sudah didaftarkan dirinya ke akun Steemit akan diarahkan untuk bergabung dengan Komunitas Steemit Indonesia (KSI) Barsela yang sudah dibentuk di Aceh Barat pada Januari 2018.

Maka secara garis besar, dapat diambil suatu kesimpulan bahwa hasil sosialisasi "Pentingnya Steemit untuk Meningkatkan Literasi dan Benefit di Dayah Darul Mutallimin Meulaboh, Aceh Barat" dapat dinilai terlaksana dengan baik. Para mahasantri dan pihak pelaksana Dayah Darul Muta'allimin merasa cukup puas, dan berharap agar ada program lanjutan bagi para mahasantri yang sudah terdaftarkan di Steemit untuk tetap dibina agar konsisten dalam menumbuhkembangkan minat berliterasi.

\section{PENUTUP}

Dari hasil pengabdian yang telah dilakukan maka dapat diambil suatu kesimpulan bahwa pemahaman Mahasantri Dayah Darul Muta'allimin terhadap penggunaan media sosial harus diperkuat guna meningkatkan literasi positif. Kurangnya akses teknologi dan mentor dalam lembaga pendidikan merupakan faktor penghambat mahasantri untuk dapat menyalurkan literasi dan memahami perkembangan sosial media positif terkini.

Adapun saran yang bisa disampaikan adalah: Penggunaan media sosial positif di kalangan masyarakat Aceh Barat yang menerapkan syariat Islam dapat ditingkatkan dengan mendorong kalangan santri untuk lebih gencar berliterasi dengan menggunakan media positif, melalui suatu pelatihan dan sosialisasi.

\section{DAFTAR PUSTAKA}

Kaplan, Andreas M.; Michael Haenlein. 2010. "Users of the world, unite! The challenges and opportunities of Social Media". Business Horizons. 
Indriati, Etty. 2015. Strategi Hindari Plagiarisme. Jakarta: PT. Gramedia.

Maulina, Putri. 2018. Analisis Peran "Steemians" dalam Komunitas Steemit Indonesia (KSI) Barsela Terhadap Literasi Positif di Aceh. At-Tanzir: Jurnal Ilmiah Prodi Komunikasi Penyiaran Islam. Hal: 49-67.

Padmadewi, I Nyoman dan Artini, Luh Putu. (2018). Literasi di Sekolah: Dari Teori ke Praktik. Bali: Nilacakra.

https://inet.detik.com/cyberlife /d-3659956/132-jutapengguna-internetindonesia-40-penggilamedsos, (diakses Kamis, 15 Maret 2018).

https://www.youthmanual.com /post/fun/did-youknow / data-penggunainternet-tahun-2017-dan-apakesimpulan-yang-bisadiambil-dari-datatersebut,(diakses Kamis, 15 Maret 2018).

http://www.acehtrend.co/darise-asia-tenggara-indonesiaterbanyak-penggunasteemit/, (diakses Kamis, 15 Maret 2018).

https:// steemit.com/indonesia/ @abunagaya/the-largeststeemit-user-graph-in-theworld-pengguna-steemit-diaceh-mencapai-100, (diakses Kamis, 15 Maret 2018). 